\title{
SUITABILITY OF AGRICULTURAL LAND OF THE HERZEGOVINA-
} NERETVA COUNTY FOR CULTIVATION OF SOME FRUIT SPECIES

\author{
Maja ARAPOVIĆ ${ }^{1}$, Perica KAPETANOVIĆ ${ }^{1}$, Marko MARJANOVIĆ ${ }^{1}$, \\ Radica ĆORIĆ ${ }^{1}$, Paulina ŠARAVANJA ${ }^{1 *}$
}

UDK 631.164(497.6 Hercegovina)

\begin{abstract}
This paper presents the evaluation of benefits of the agricultural land for the cultivation of cherry, sour cherry, plum and apple in the area of Herzegovina-Neretva County (HNC). The evaluation of the land suitability was carried out according to the FAO method (FAO, 1976, Brinckman and Smith, 1973), according to the agro zone (up to $800 \mathrm{~m}$ above sea level) and taking into account the features of the soil, climate and topography and the requirements of these fruit cultures. The results of the research are shown with text and graphics (maps of benefits of the agricultural land). Based on the conducted research, the existence of significant and valuable land resources is established for development of fruit cultivation in Herzegovina-Neretva county.

For the cherry and sour cherry cultivation in the agricultural area of HerzegovinaNeretva county (up to $800 \mathrm{~m}$ above sea level) exists 29,682 hectares $(28.55 \%)$ of suitable land, for the plum and apple cultivation exist 38,345 hectares $(36.89 \%)$. The convenience of the class structure of the soil for the cherry, sour cherry, plum and apple is the smallest share of the P-1 class benefits. The largest proportion of the land P-3 class benefits for growing cherries, sour cherries, apples and plums with benefits in the soil for growing cherries have less difference between the surfaces of the P-2 and P-3 class suitability. The main limitations are the slope of the terrain, the depth of profile, rockiness and stoniness. Temporarily unsuitable soils had occupied significant area for these fruit species cultivation. Plots of this class can be with adequate, economically justified measures led to a certain class of convenience
\end{abstract}

Keywords: agricultural land, facility, cherry, sour cherry, climate, relief

\section{INTRODUCTION}

A rational use of the pomological and ecological potential of a production area is the foundation for sound growth and abundant and regular yield of fruit trees. To plan the

\footnotetext{
${ }^{1}$ Faculty of Agriculture and Food Technology, University of Mostar, Biskupa Čule bb, 88000 Mostar Bosnia and Herzegovina

*Corresponding author: paulina.saravanja@sve-mo.ba
} 
development of fruit growing in a certain area, it is important to evaluate and define the degree of suitability of ecological conditions for cultivation of fruit trees, because fruit trees remain in the same place for many years. The Herzegovina-Neretva County (HNC) has a tradition in the production of fruits. Different climatic conditions, from Mediterranean to continental, provide the possibility of producing all types of continental and certain types of mediterranean fruits. The aim of this study was to determine the characteristics of soils, climate and relief in the area of agricultural soil/land of the Herzegovina-Neretva County as ecological factors of fruit production, and taking into consideration the criteria and requirements of the studied fruit species (sweet cherry, cherry, plum, apple), to evaluate the suitability of agricultural soils/land for their cultivation.

\section{MATERIAL AND METHODS}

The compilation soil map of agricultural land of the Federation of $\mathrm{BiH}$ at the scale 1:200,000 was used as the basis for preparation of this paper. This map was used as a basis to make a soil map excerpt for the Herzegovina-Neretva County (HNC), based on which the characteristics of soils/land are presented in this paper.

Well suitable soils of the P-1 suitability class include areas without significant limitations for cultivation of particular fruit species or with limitations that will not significantly affect the productivity and profits of production. Moderately suitable soils of the P-2 suitability class cover areas with limitations that moderately affect the productivity and profits of production of particular fruit species. The P-3 suitability class soils, suitable to a limited degree, cover areas with limitations that significantly compromise the productivity and profits of production of particular fruit species. Temporarily unsuitable soils of the N-1 suitability class are areas with limitations that can be improved by certain agricultural engineering interventions. Permanently unsuitable soils of the N-2 suitability class cover areas with limitations that rule out any possibility of economically justified production of those fruit species.

Data on climate were obtained from the Federal Hydrometeorological Institute. The requirements of particular fruit species were determined on the basis of the existing literature. For cultivation of apples, the best an average air temperature is $20^{\circ} \mathrm{C}$ during the growing season. The necessary precipitation for cultivation apples is about $600 \mathrm{~mm}$ during the growing season. For cultivation of plums the best average air temperatures are between $16^{\circ} \mathrm{C}$ and $20^{\circ} \mathrm{C}$ during the growing season. The necessary precipitation for cultivation plums is between $400-500 \mathrm{~mm}$ during the growing season. Cherry is growing in areas where an average annual air temperature ranges from $10^{\circ} \mathrm{C}$ to $17^{\circ} \mathrm{C}$. Minimum precipitation for cultivation cherries is about $500 \mathrm{~mm}$ during the growing season. For cultivation sour cherries, temperature requirements are similar to requirements cherry, except that the lower limit for growing cherries is $650 \mathrm{~mm}$ of precipitation per year (Miljković, I., 1991; Šoškić, M. M., 2008). 
Slightly hilly terrains (with slopes up to $10 \%$ ) are the most favorable for the production of fruits. Slope gradients for fruit production should certainly not exceed $15 \%$. Costs of terracing are significantly increased if slope gradient is greater than $15 \%$, while positions with slopes greater than $30 \%$ are considered unsuitable for cultivation of fruit trees. Deep soil, fine textured soil, good physical and chemical properties, biologically active, neutral to slightly acid reaction are suitable soil for the fruit cultivation. Unsuitable soils for the fruit cultivation are shallow soils, very rocky and stony soils and heavy, dense, calcareous or acid soils with impermeable lower horizons (Miljković, I., 1991; Šoškić, M. M., 2008).

The land suitability evaluation was carried out according to the FAO method (FAO, 1976; Brinckman and Smith, 1973) for agricultural land in the area of HNC, specifically for the area up to $800 \mathrm{~m}$ above sea level. Based on results of the suitability evaluation of dominant soil types in mapped units, a special-purpose interpretation of the soil map of agricultural land was conducted, on the basis of which a map of suitability for cultivation of particular fruit species was made.

\section{RESULTS AND DISCUSSION}

\section{Climate characteristics}

The fundamental factors that determine the selection of fruit species to be grown in a particular area and affect the profitability of fruit production in that connection are the natural conditions, that is climate, relief, altitude and slope, and soil or land (depth, physical and chemical properties, participation of rocks on the soil/land surface, participation of stones on the soil/land surface, soil texture in surface horizon, permeability of soil, infiltration of water in the soil).

The area of $\mathrm{HNC}$ is an exceptionally heterogeneous area the agroecological conditions of which are defined by the proximity of the sea, articulated mountainous relief and river flows. The mountainous, moderately continental and mediterranean belt, each with its specificities, alternate in this area. According to data obtained from the Federal Hydrometeorological Institute for the period 2004-2013, the coldest month was January with an average air temperature of $4.3^{\circ} \mathrm{C}$, and the warmest month was July with an average air temperature of $26.1^{\circ} \mathrm{C}$. The average annual air temperature ranged from $10.6^{\circ} \mathrm{C}$ to $16.2^{\circ} \mathrm{C}$. The average annual precipitation for the observed period was $1,580.2$ $1 / \mathrm{m}^{2}$, and the average monthly precipitation ranged from $42.1 \mathrm{l} / \mathrm{m}^{2}$ in July to $175.221 / \mathrm{m}^{2}$ in November.

\section{Relief characteristics}

The maps of terrain altitude and slope were made for the purpose of evaluating the suitability of agricultural land for cultivation of fruit species. Considering that slope and 
height above sea level of the terrain (area) may represent major limitations for fruit growing, certain areas are treated as permanently unsuitable for fruit growing.

Analysis of the data of individual terrain altitude classes (Figure 1) shows that in the Herzegovina-Neretva County altitudes of more than 1,200 m occupy most of the terrain area $(109,459.4 \mathrm{ha})$, while the area of altitudes from 1,000 to $1,200 \mathrm{~m}$ occupies the smallest part $(30,011.5 \mathrm{ha})$. The terrain of altitudes up to $800 \mathrm{~m}$ in $\mathrm{HNC}$ covers the area of 255,153 ha.

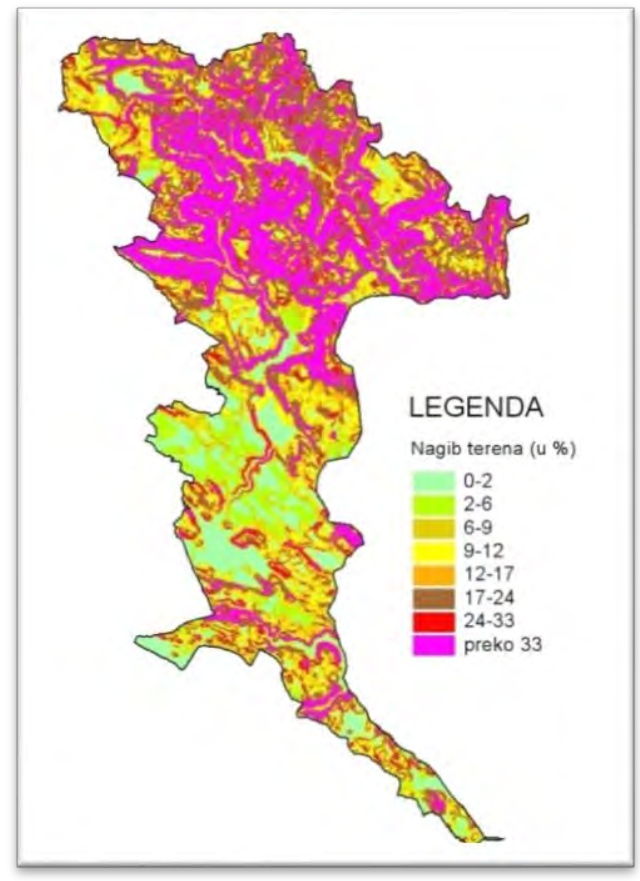

Figure 1. Terrain altitudes of the HNC area

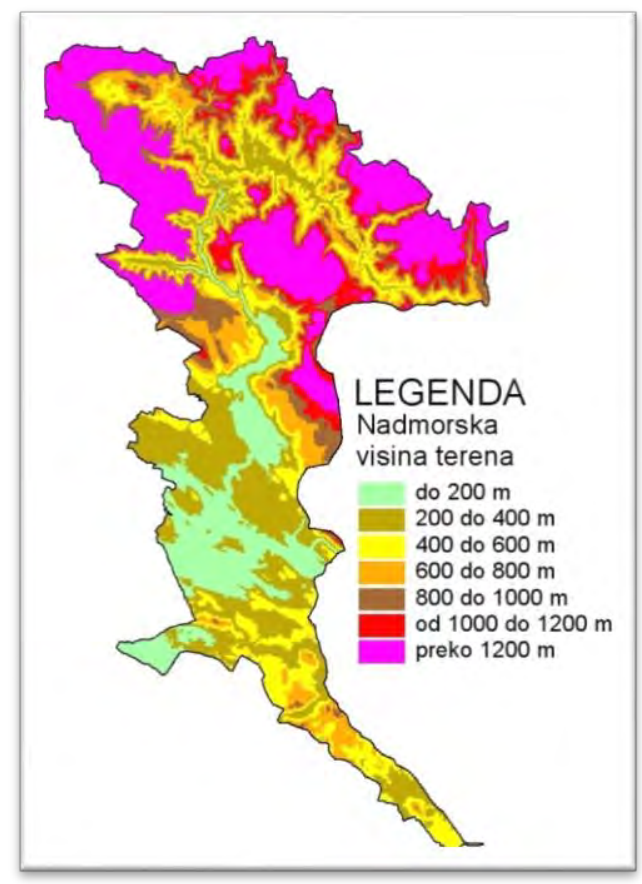

Figure 2. Terrain slopes of the $\mathrm{HNC}$ area

Source F1 \& F2: Corić et al., 2013

Arable areas are mainly limited to sinkholes, depressions, clearings, plateaus, mild slopes protected from erosion and valleys of rivers and watercourses provided that there is no danger of flooding. Special arable resources are related to karst fields and karst plateaus (Ćorić et al., 2013).

Hillsides with their slopes are an important element of the relief (Figure 2). In the area of $\mathrm{HNC}$, it is visible that the area with slope gradient from 17 to $24 \%$ occupies $109,457.9$ ha, and the terrain with slope gradient from 24 to $33 \%$ covers the smallest area of 19,978.8 ha. The terrain with slope gradient from 0 to $17 \%$ occupies the area of 204,930 ha. 


\section{Soil characteristics}

An excerpt of the soil map of agricultural land in the area of HNC (Figure 3) was made on the basis of the soil map of $\mathrm{BiH}$ at the scale 1:200,000 (Source: Federal Institute for Agropedology, Sarajevo) and the altitude map. In geological terms, the area of HNC is very complex. Consistent with the set of pedogenetic factors, different types of soil are developed in the area of Herzegovina-Neretva County. They are classified into two divisions, specifically the division of automorphic and the division of hydromorphic soils. The division of automorphic soil types that are found in the area of HNC includes the following: sierozem (regosol), colluvium, lime dolomite black soil (calcomelanosol), humus silicate soil (ranker), rendzina, eutric brown soil (eutric cambisol),

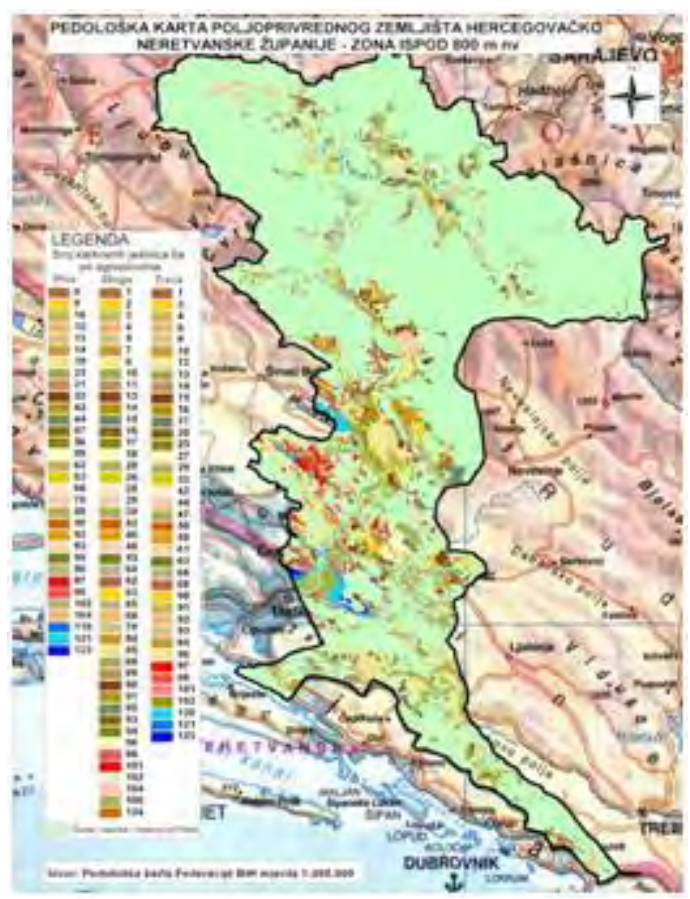

Figure 3. Soil map of agricultural land of HNC Source: Federal Institute for Agropedology, Sarajevo distric brown soil (cistric cambisol), red soil (terra rossa), brown soil on limestone and dolomite (calcocambisol) and loessivized soil (luvisol). The hydromorphic division includes these types of soil: alluvial (fluvial) soils, marshy-gleyic soil (eugley), fluvial meadow (humofluvisol) and peat soil. Automorphic soils are all soils the formation and development of which is characterized by wetting only by precipitation, and percolation of rainwater is free and without long retention in the soil profile. Hydromorphic soils are characterized by regular or occasional wetting by excess underground, flood or flow water from higher terrains. The basic characteristics of particular types of soil are presented in detail in the existing literature (Škorić, A., 1986). For the purposes of soil suitability evaluation, characteristics of mapped units (up to $800 \mathrm{~m}$ asl) were established, which include: terrain slope, stoniness,

rockiness, altitude, soil texture, drainage, mode of wetting, ecological depth and parent substrate, which more fully characterize individual systematic and mapped soil units. 
The evaluation of suitability of agricultural land in the area of HNC for the cultivation of sweet cherry, cherry, plum and apple trees

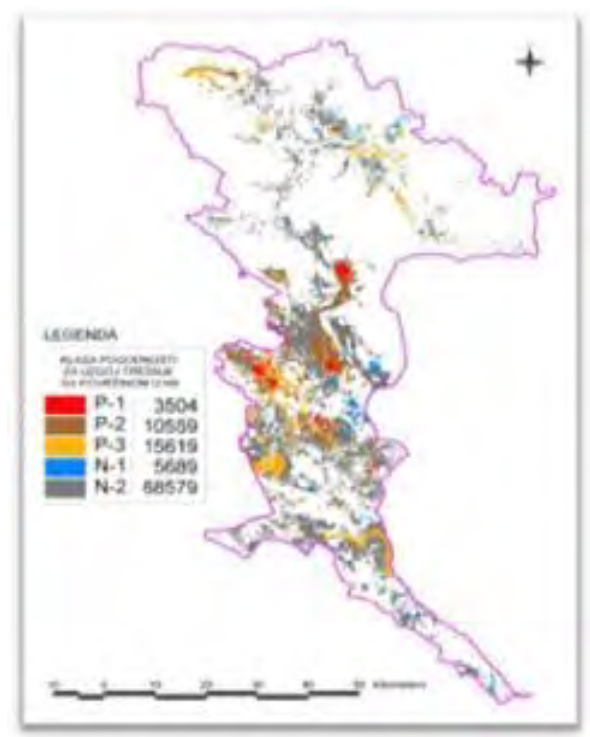

Figure 4. Sweet cherry cultivation suitability map

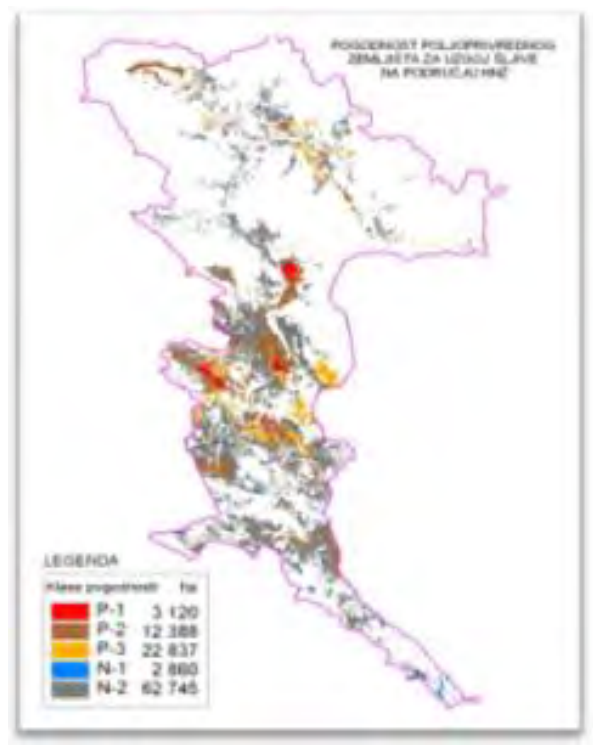

Figure 6. Plum cultivation suitability map

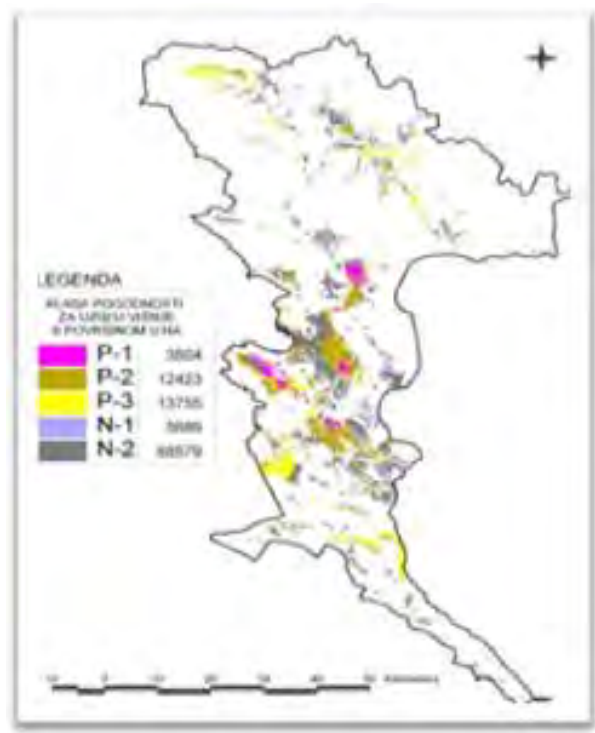

Figure 5. Cherry cultivation suitability map

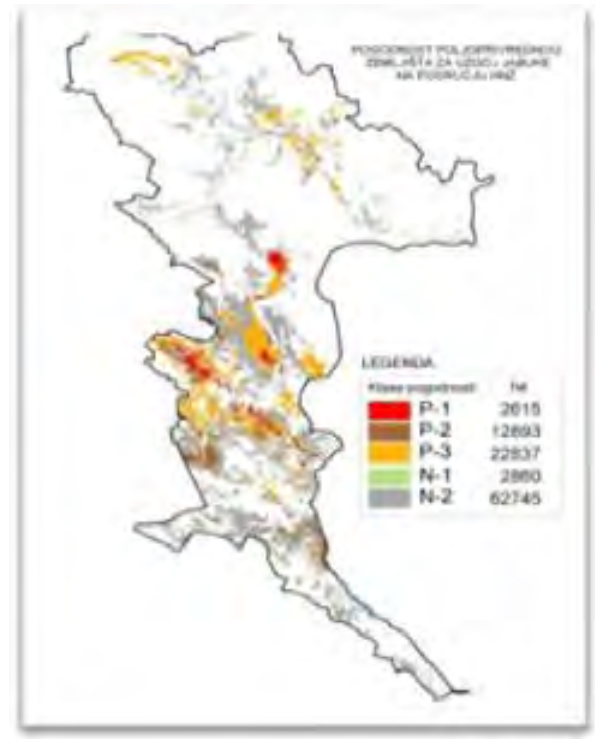

Figure 7. Apple cultivation suitability map Source: Ćorić et al., 2013 
Based on results of the evaluation of suitability of only and/or dominant soil type in mapped units and ectomorphological characteristics, evaluation of suitability of agricultural land for the cultivation of sweet cherry, cherry, plum and apple trees was carried out, and then the inventory of areas by suitability orders and classes was conducted. Spatial distribution of individual classes is shown on the suitability maps for cultivation of these fruit species in the area of Herzegovina-Neretva County (Figures 4., 5., 6., and 7.).

Analysis of the obtained data shows that in the total area of agricultural land of HNC (up to $800 \mathrm{~m}$ asl) the P-1 class soils for the cultivation of sweet cherry and cherry trees occupy the area of 3,504 ha $(3.37 \%)$, and for the cultivation of plum trees 3,120 ha $(3.00 \%)$ and apple trees 2,615 ha $(2.51 \%)$.

In the area of $\mathrm{HNC}$, the P-2 suitability class land for the cultivation of sweet cherry trees occupies 10,559 ha $(10.16 \%)$, for the cultivation of cherry trees 12,423 ha (11.95\%), for the cultivation of plum trees 12,388 ha (11.92\%) and for the cultivation of apple trees $12,893 \mathrm{ha}(12.40 \%)$. These areas for the cultivation of sweet cherry trees cover 15,619 ha $(15.03 \%)$, for the cultivation of cherry trees 13,755 ha $(13.23 \%)$, for the cultivation of plum trees 22,837 ha $(21.97 \%)$, and for the cultivation of apple trees 22,837 ha $(21.97 \%)$.

In the studied area, these soils for the cultivation of sweet cherry and cherry trees cover 5,689 ha (5.47\%), for the cultivation of plum trees and apple trees 2,860 ha (2.75\%). Most of these areas are found for the cultivation of sweet cherry and cherry trees, 68,579 ha (65.97\%), for the cultivation of plum trees and apple trees 62,745 ha $(60.36 \%)$, Table 1.

The main limiting factors for the cultivation fruits are: climate (occurrence and frequency of the spring and autumn frosts, low temperatures during flowering and fructification, excessive temperature during the growing period, insuficiency of water especially during the growth and development of the fruit), slope (positions with slopes greater than $30 \%$ are considered unsuitable for cultivation of fruit trees), soil depth (shallow soils), stoniness, rockiness (soils with a high percentage of rocks and/or stones).

Table 1. Inventory of areas (ha) of soil suitability classes for the studied fruit species

\begin{tabular}{ccccc}
\hline Class & sweet cherry & cherry & plum & apple \\
\hline \hline P-1 & 3,504 & 3,504 & 3,120 & 2,615 \\
P-2 & 10,559 & 12,423 & 12,388 & 12,893 \\
P-3 & 15,619 & 13,755 & 22,837 & 22,837 \\
\hline N-1 & 5,689 & 5,689 & 2,860 & 2,860 \\
\hline N-2 & 68,579 & 68,579 & 62,745 & 62,745 \\
\hline
\end{tabular}




\section{CONCLUSIONS}

The conducted research established the presence of significant land resources for the development of fruit production in the area of the Herzegovina-Neretva County. In the area of the county (up to $800 \mathrm{~m}$ asl), there are $29,682 \mathrm{ha}(28.55 \%)$ of land of various suitability degrees for the cultivation of sweet cherry and cherry trees, and for the cultivation of plum trees, and apple trees 38,345 ha $(36.89 \%)$.

Thus, the total suitability areas for the cultivation of sweet cherry and cherry trees are the same primarily because of very similar requirements of the studied fruit species for agro ecological factors. In the structure of suitability classes for cherry trees, there is a slightly larger proportion of the P-2 suitability class primarily due to somewhat more modest requirements of this fruit species. The P-3 suitability class soils for the cultivation of sweet cherry, cherry, apple trees and plum trees have the highest occurrence. The P-1 suitability class soils have the lowest occurrence for all the studied fruit species. For the cultivation of sweet cherry trees and cherry trees the P-1 suitability class soils have the highest occurence than compared to all the studied fruit species, which greatly contributes to the high presence of calcareous soils in this area.

In fruit growing, specific agro ecological and soil conditions, as well as selection of the most appropriate cultivar for specific cultivation areas, can significantly increase the productivity of this branch of economy. Therefore this type of research should help improve production of fruits in the Herzegovina-Neretva County.

\section{REFERENCES}

Arapović, M. 2014. Suitability of agricultural land for the cultivation of plum trees in the area of Herzegovina-Neretva County. Graduation thesis, University of Mostar, Faculty of Agronomy and Food Technology.

Brinkman, R. and A.J. Smyth. 1973. Land Evaluation for Rural Purposes. Summary of an Expert Consultation, Wageningen, the Netherlands, 6-12 October 1972. Publication No. 17. International Institute for Land Reclamation and Improvement, Wageningen, the Netherlands. pp.116.

Ćorić,R. et al. 2013. Multipurpose valuation of land of FBiH. Federal Ministry of Agriculture, Water Management and Forestry, Sarajevo.

FAO, 1976. A framework for land evaluation. Soil Bull. No.32. FAO, Rome and ILRI, Wageningen Publ. No.22.

Federal Hydrometeorological Institute of $\mathrm{FBiH}$.

Federal Institute for Agropedology, Sarajevo.

Kapetanović, P. 2014. Suitability of agricultural land for the cultivation of apple trees in the area of Herzegovina-Neretva County. Graduation thesis, University of Mostar, Faculty of Agronomy and Food Technology. 
Marjanović, M. 2015. Establishing the suitability of land of the Herzegovina-Neretva County for the cultivation of sweet cherry and cherry trees. Graduation thesis, University of Mostar, Faculty of Agronomy and Food Technology.

Miljković, I. 1991. Suvremeno voćarstvo. Znanje, Zagreb.

Škorić, A. 1986.Postanak, razvoj i sistematika tla. Faculty of Agricultural Sciences University of Zagreb, Zagreb.

Šoškić, M. M. 2008. Suvremeno voćarstvo. Drugo izmenjeno izdanje. Partenon, Beograd. 